\title{
Forest fragments and natural vegetation patches within crop fields contribute to higher oilseed rape yields in Brazil
}

\author{
Rosana Halinski ${ }^{\mathrm{a}, *}$, Lucas Alejandro Garibaldi ${ }^{\mathrm{b}, \mathrm{c}}$, Charles Fernando dos Santos ${ }^{\mathrm{c}}$, \\ André Luis Acosta ${ }^{\mathrm{d}}$, Daniel Dornelles Guidi ${ }^{\mathrm{c}}$, Betina Blochtein ${ }^{\mathrm{c}}$ \\ ${ }^{a}$ Escola Politécnica, Pontifícia Universidade Católica do Rio Grande do Sul, Avenida Ipiranga, 6681, 90619-900 Porto Alegre, Rio Grande do Sul, Brazil \\ ${ }^{\mathrm{b}}$ Universidad Nacional de Río Negro. Instituto de Investigaciones en Recursos Naturales, Agroecología y Desarrollo Rural. San Carlos de Bariloche, Río Negro, Argentina. \\ ${ }^{c}$ Consejo Nacional de Investigaciones Científicas y Técnicas. Instituto de Investigaciones en Recursos Naturales, Agroecología y Desarrollo Rural. San Carlos de Bariloche, \\ Río Negro, Argentina. \\ ${ }^{\mathrm{d}}$ Departamento de Ecologia, Instituto de Biociências, Laboratório de Ecologia de Paisagens e Conservação - LEPAC, Universidade de São Paulo, Rua do Matão, Travessa \\ 14, N³21, 05508-090 São Paulo, Brazil
}

\section{A R T I C L E I N F O}

\section{Keywords:}

Canola

Ecosystem services

Forest fragments

Income

Productivity

Yield

\begin{abstract}
A B S T R A C T
Ecosystem services are fundamental to the maintenance of biodiversity, food security, livestock and biofuel production. Here, we analyze the impact of the distance between forest fragments and oilseed crops (Brassica

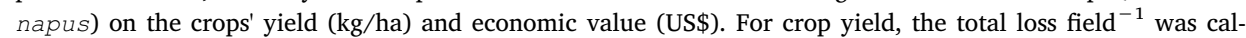
culated as the difference between the most lucrative parcel and the least lucrative parcel. Hypothetical models were developed to estimate the potential changes in crop incomes due to progressive replacement of the lowest income crop area(s) by natural vegetation. Our findings demonstrate a significant decrease in the mean number of seeds per silique and in seed production as the distance from forest fragment progressively increases. The productivity loss throughout this gradient may reach up to $2760 \mathrm{~kg} /$ ha (i.e. US\$804.08). Our models indicate that parcels further than $325 \mathrm{~m}$ from forest fragments were poorly pollinated. Our models also demonstrated that farmers could boost their yields if more natural areas (as small as 5\%) were included inside crop fields, even though this reduces their arable area. In conclusion, adding small natural patches within crop fields will most likely lead to a higher seed production and successive increases in the economic value of canola crops.
\end{abstract}

\section{Introduction}

Ecosystem services are processes attributed to both ecosystems and organisms that sustain human life (Daily, 1997), and they have high economic values. They have been estimated to have a value of 33 trillion dollars per year, 112 billion of which is accounted for by pollination services (Costanza et al., 1997). In 2009, according to Gallai et al., the global value of ecosystem services was estimated at 200 billion dollars. In South America alone, the value of pollination services has been estimated at 11.6 billion euros per year (Potts et al., 2010), while bee pollination in Brazil has been valued at around US\$12-14 billion (Giannini et al., 2015; Novais et al., 2016).

Pollination services provided by bees and other organisms lead to increases in the quality, productivity and stability of $75 \%$ of crops worldwide (Klein et al., 2007). The ecosystem service of pollination is important for the maintenance of biodiversity and food production, because efficient flower pollination produces fruits and seeds that are both qualitatively and quantitatively better (Ricketts et al., 2008; Aizen et al., 2009; Lautenbach et al., 2012; Klatt et al., 2013). Studies on agricultural crops have shown that crop productivity is reduced following changes to landscapes adjacent to crop fields and the consequent loss of pollinating agents (Klein et al., 2003; Vaissière et al., 1996; Vicens and Bosch, 2000; Durán et al., 2010). Other studies have shown a decline in the rate of flower visitation with an increase in the distance to the edge of forest fragments, especially for social and solitary bees (Bailey et al., 2014; Chacoff and Aizen, 2006; de Marco and Coelho, 2004; Féon et al., 2013; Hipólito et al., 2018; Ricketts et al., 2004). This is most likely due to their need of natural habitats not only for food resources but also as nesting and breeding sites (Chacoff and Aizen, 2006; Knight et al., 2009; Steffan-Dewenter and Tscharntke, 1999).

Since Brazil is one of the world's largest agricultural producers, public policies have been created to incentivize the production of food and biofuels. The oleifera variety of Brassica L., known as oilseed rape

\footnotetext{
* Corresponding author.

E-mail address: ro.halinski@gmail.com (R. Halinski).
} 
(canola), is a perfect example of such a plant. Canola is the third most widely produced oilseed crop in the world. Its highest consumption rate is found in developed countries (USDA, 2016), and an area of 35.7 million hectares has been cultivated to produce 65 million tons per year (FAOSTAT, 2016). The seed production industry has recently grown in Brazil, where it is focused on the production of commercial oil for human consumption and biofuel production (Conab, 2019).

Studies have shown that canola has a period of self-fertility, and it is known that pollinator visits can promote an increase in productivity (Abrol, 2007; Blochtein et al., 2014; Mcgregor, 1976; Rosa et al., 2010; Sabbahi et al., 2005; Durán et al., 2010). There are many studies evaluating the importance of forest fragments as relevant providers of pollinating organisms, which increase the yield of oilseed rape crops (Bailey et al., 2014; Bartomeus et al., 2015; Féon et al., 2013; Morandin and Winston, 2005; Witter et al., 2015). In the past decades an innovative ecological approach has emerged in which designs of agricultural landscapes have been rethought to optimize the ecosystem services provided, e.g., by pollinating organisms (Bondin et al., 2006; Brosi et al., 2008; Carvalheiro et al., 2012; Isaacs et al., 2017; Landis, 2017; Picanço et al., 2017).

Same studies have suggested hypothetical and/or empirical models in which the maximum pollination coverage could be achieved on poorly pollinated parcels (core areas) if they were replaced by uncultivated and native plants (Bondin et al., 2006; Brosi et al., 2008; Carvalheiro et al., 2012; Isaacs et al., 2017; Landis, 2017; Picanço et al., 2017). Such parcels significantly increase the number of wild pollinators inside crops (Blaauw and Isaacs, 2014; Carvalheiro et al., 2012; Isaacs et al., 2017). Therefore, not only the edges of forest fragments but also natural vegetation patches within crops could be considered as pollinator reservoirs, enlarging the richness and abundance of bees. Consequently, pollination services would be optimized and maximum pollination coverage obtained within crop fields (Bondin et al., 2006; Brosi et al., 2008; Carvalheiro et al., 2012; Landis, 2017; Lonsdorf et al., 2009; Morandin and Winston, 2006; Picanço et al., 2017; Ricketts et al., 2008).

We analyzed the effect of forest fragments on the yield and economic value of canola and built hypothetical models simulating different and ascending levels of land area conversion, from planted areas (the lowest income parcels) to natural vegetation. Potential scenarios where an increase in the contact between crops and natural vegetation patches could rise the pollination level and, consequently, provide income/productivity benefits for the farmer were evaluated. This approach was compared with the potential costs of such a method as the arable area is reduced.

\section{Material and methods}

\subsection{Study area}

The study was conducted in four crop fields with Brassica napus (Hyola 420) in southern Brazil: field 1 (20 ha); field 2 ( 80 ha); field 3 (100 ha) and field 4 ( 80 ha). A crop rotation system is used in these areas, whereby corn and soybean are planted in the summer and canola and wheat are planted in the winter. The study areas were located in the ecoclimatic region of the Planalto Superior Serra do Nordeste, with mean temperatures between 14.4 and $16.8{ }^{\circ} \mathrm{C}$, relative humidity levels between 76 and $83 \%$ and annual precipitation levels between 1412 and $2162 \mathrm{~mm}$ (Veloso et al., 1992). According to the Köppen climate classification the climate of the region is humid temperate (Vianello and Alves, 1991) and the predominant ecosystems are subtropical forests, forests with Paraná Pine (Araucaria sp.) and meadows.

\subsection{Sampling design}

Eleven to eighteen canola plants, which were spaced $1.5 \mathrm{~m}$ from each other and formed parcels of $225 \mathrm{~m}^{2}$, were selected from each of the four fields and harvested to analyze the production of siliques and seeds open to insect visitation. Within each field, a parcel was sampled at 25, 175 and $325 \mathrm{~m}$ from the edge of forest fragments. The canola plants were harvested after the siliques were mature; in fields 1 and 2 they were harvested on the 9th of October 2010, and in fields 3 and 4 they were harvested on the 31 st of October 2011. The plants were collected and stored in a freezer at $-10{ }^{\circ} \mathrm{C}$ until the numbers of formed and aborted siliques, in addition to the number of flowers per plant, were counted. The siliques were threshed separately and dried in an oven (at $40^{\circ} \mathrm{C}$ ). After this procedure the number of seeds per plant was manually counted (in hundreds) with the aid of a vacuum seed counter (ERICKSEN De Leo, Porto Alegre, Brazil).

\subsection{Production components and characteristics of each plant}

Eight production components of canola seeds were analyzed: (a) mean number of flowers, (b) mean number of flowers per hectare, (c) fruit set rate, (d) mean number of siliques, $(e)$ mean number of seeds per silique, $(f)$ mean number of seeds per plant, $(g)$ total mean weight of seeds and $(h)$ weight of a thousand seeds.

The number of flowers per plant was manually counted, the totals were summed and then divided by the total number of plants sampled to give the mean number of flowers $(a)$. Subsequently, the number of flowers per hectare $(b)$ was calculated by multiplying the mean total number of flowers by the total number of plants per hectare. The fruit set rate $(c)$ was calculated by dividing the mean number of siliques per plant by the mean number of flowers per plant. The mean number of seeds per silique $(e)$ was determined by manually counting the seeds of ten siliques per plant, which were randomly sampled in every field at each distance from the edge of the forest fragment. The mean number of seeds per plant $(f)$ was calculated by dividing the mean of number of seed by the total of plants. The mean total weight of seeds $(g)$ per plant (in grams) was calculated by the sum individual weight of the plants, with the aid of a high precision analytic balance (AUY200), by the number of plants. Thereafter, the weight of a thousand seeds $(h)$ was calculated by multiplying the total of weight of the sample by 1000 , which was then divided by the total number of seeds. In addition to productivity, plant density per field was measured by counting the number of plants, as well as recording the distance between the bases of the plants, along ten one meter long randomly chosen transects.

\subsection{Economic value and seed yield}

To analyze the productivity of canola seeds, the plants were harvested in parcels of $225 \mathrm{~m}^{2}$. Later, this initial area $\left(225 \mathrm{~m}^{2}\right)$ was extrapolated to $10,000 \mathrm{~m}^{2}$ ( $1 \mathrm{ha}$ ). Production measures were taken after the seeds were harvested, counted, threshed, cleaned, dried and weighed, as previously mentioned.

The mean total weight of the sample at each distance from a forest edge (converted to kilos and extrapolated to $1 \mathrm{ha}$ ) was used to compare the productivity of canola seeds. Then, the yield per hectare for each distance was calculated considering that a canola sack $(60 \mathrm{~kg})$ is valued at US\$17.48 (Conab, 2019). To obtain the total yield of a given field, the yield per hectare at the selected distance from the forest fragment was multiplied by the number of hectares within the field. We used the yield of all fields to calculate the total yield loss per sampled field, using the difference between what we assumed to be the most lucrative $(25 \mathrm{~m})$ and the least lucrative $(325 \mathrm{~m})$ parcels.

To obtain the total yield of a given field, the yield per hectare at each distance from the forest edge was multiplied by the number of hectares of each field while also taking into consideration the mean weight of seeds at each distance. For the projected yields, we considered that all crops from the sampled fields were planted at either 25, 175 or $325 \mathrm{~m}$ from a forest fragment. With the projected yields of the fields, the total loss per field sampled was calculated using the difference between the most lucrative $(25 \mathrm{~m})$ and the least lucrative $(325 \mathrm{~m})$ 
parcels.

\subsection{Data analyses}

This study aims to evaluate and compare whether the production components and characteristics (a-g) evaluated per plant could be different from each other at the significance level $<0.05$. Firstly, the normality of the production components and characteristics, that were evaluated per plant, were analyzed using both a visual approach (e.g. histograms, qqplot) and statistical analyses (e.g. Shapiro test, Bartlett test). The tests rejected HO pointing to non-normal distribution of the sample. For this reason, non-parametric tests like permutational analysis of variance (permutation one-way ANOVA) were used assuming similar variance of distributions and could be interpreted as a test of means. This permutation was repeated 999 times to allow us to generate a great number of scenarios and produce a reliable F-values. This approach empirically generated a normal distribution by randomly shuffling the class variables within the dataset. Hence, every production component or characteristic evaluated per plant (a-h) was considered as a response variable and the distance from forest fragments $(25,175$ or $325 \mathrm{~m}$ ) was dealt with as one factor (note: the fields could have been handled as blocks, but because the experimental design was unbalanced this was not possible). The permutation ANOVA was performed using the function perm.anova in the RVAideMemoire package (Hervé, 2015) for R (Ihaka and Gentleman, 1996; R Core Team, 2019).

Pairwise multiple comparisons were performed using the function nparcomp, from the nparcomp package (Konietschke et al., 2015), to compute the nonparametric relative contrast effects and their respective $p$-values. The contrast of these comparisons was set as "Tukey". This test was suitable for our purposes and enabled us to determine statistical differences among the productivity parameters.

Finally, a linear mixed model (LMM) was performed to evaluate if the grain weight of canola seeds (response variable) could be explained by distance from a forest fragment (fixed effects). As random effects, slopes were used to represent distances and intercepts represented fields. Visual inspection of residual plots did not reveal any obvious deviations from homoscedasticity or normality. This analysis was also carried out in R (Ihaka and Gentleman, 1996; R Core Team, 2019) using the function lmer from the lme4 package (Bates et al., 2015).

\subsection{Mapping and buffering distances from natural vegetation}

Georeferenced points were recorded in the field along the border of each canola crop surveyed (referred to as Fields 1 to 4). ArcGIS (ESRI, 2010) was used to map crop fields (1) and their adjacent natural vegetation fragments (2) using georeferenced aerial images from Google Earth (Google Inc.).

A sequence of adjacent external buffers was generated from each natural vegetation patch (hereinafter NVP), surrounding the crops at intervals of $25 \mathrm{~m}(25 \mathrm{~m}, 50 \mathrm{~m}, 75 \mathrm{~m}$ and so on until the maximum distance; each buffer is hereinafter referred to as a ring). Since the effect of natural vegetation on the income of crops is known, it was possible to cover each crop field with its respective income value (USD) which was determined by its relative distance from a NVP. The generated rings were clipped to the extent of the crops, thus, only rings inside the crops were kept.

\subsection{Calculating model variables}

The total area of each crop was mapped (Fields 1 to 4 ), as was the area of each ring inside it. The proportion (percentile) covered by every ring in each respective crop was also calculated. The mapped georeferenced crop size was used while the farm owner provided the crop area. Thus, the proportions used to calculate the ring areas (in hectares) was based on the total area provided by the farm owner. For instance, the first georeferenced ring in Field 1 ( $25 \mathrm{~m}$ from a NVP) encompasses about $22.7 \%$ of the total georeferenced mapped area. Considering the reported size of Field $1=20$ ha, this ring covers 4.54 ha $(22.7 \%$ of 20 ha $=4.54$ ha). The same rationale was used to calculate the income per ring (e.g. ring no. 1 of Field $1=570$ USD per ha, thus the total income for the 4.54 ha of ring no. $1=2592$ USD) and to estimate the area lost within the models.

\subsection{Modelling approach}

A simple method was used to generate five models for each crop field based on the progressive replacement of planted areas by NVPs, increasing the size of the replaced area across the models. Since the income value for each distance of the crops to a NVP were known, it was possible to develop the first model identifying and replacing the lowest income ring by a NVP. Subsequently in the second model, the second lowest income ring was also replaced by a NVP. This procedure was repeated until the five lowest income rings were replaced by NVPs.

The replacement of low-income rings by NVPs reconfigured the spatial distribution of incomes over the crop fields, since the distance of crop fields from natural vegetation patches decreased (in fact, many fields became adjacent to a NVP). This proximity to vegetation consequently has the potential to improve farmers' income. However, the conversion of planted areas to NVPs also reduces the total amount of planted area per crop. For each model, the potential income gain per crop (resulting from the increased contact with a NVP), as well as the loss of income per crop (resulting from planted areas being converted into NVPs), were compared and evaluated.

The size of the NVP needs to be large enough to effectively provide resources and maintain pollinator populations inside crop fields. Therefore we considered the possibility that the NVP of model 1 could be too small to be effective. This was expected to depend on the total crop size. To evaluate this, the minimum NVP size required to provide a suitable habitat for pollinators was calculated.

\section{Results}

\subsection{Seed data and monetary value}

We found 40 plants $/ \mathrm{m}^{2}$ at every distance in each field, producing a total count of approximately 91,132.000 flowers per hectare (component $b$ ). This made it possible to analyze the mean number of flowers and siliques per plant to determine if fields yielded similar results. An exception was found in Field 3 where these parameters significantly decreased at each consecutive distance from the NVP (Table 1).

With respect to fruit set rate (component $c$ ), a significant difference was found in Field 2 between the distances $25 \mathrm{~m}$ and $325 \mathrm{~m}$, as well as between $175 \mathrm{~m}$ and $325 \mathrm{~m}$, with a variation rate of $72.7 \%$ to $88.6 \%$ between all of the distances. In other fields, this parameter was not significant (Table 1). When examining the mean number of seeds per silique (component $e$ ), a significant decrease occurred along the distance gradient, from 25 to $325 \mathrm{~m}$, in every field except Field 4 (Table 1), which showed significant differences $\left(\mathrm{F}_{1,36}=2.25, p>.05\right)$ between the parcels located at distances of 25 and $175 \mathrm{~m}$ from the edge of a forest fragment. Furthermore, when examining the mean number of seeds per plant (component $f$ ) significant differences were found between the parcels along the distance gradient in Field 3(Table 1). The other fields did not show this pattern.

For the parameter of the weight of a thousand seeds, a significant difference was found between distances along the distance gradients in all fields (Field 1: $\mathrm{F}_{1,36}=10.92, p<.05$; Field $3: \mathrm{F}_{1,36}=5.07$, $\mathrm{p}<.05$ and; Field 4: $\left.\mathrm{F}_{1,36}=11.38, \mathrm{p}<.05\right)$ except Field 2 $\left(\mathrm{F}_{1,36}=1.87, \mathrm{p}>.05\right)$ (Table 1$)$. The mean seed weight per plant (component $f$ ) decreased with distance from a forest edge in every field, with the lowest values found in the interiors of the fields (Table 1). This decrease was significant between the distances of 25 and $325 \mathrm{~m}$ in all fields (Field 1: $\mathrm{F}_{1,36}=6.60, \mathrm{p}<.05$; Field 2: $\mathrm{F}_{1,36}=15.65, \mathrm{p}<.05$ 
Table 1

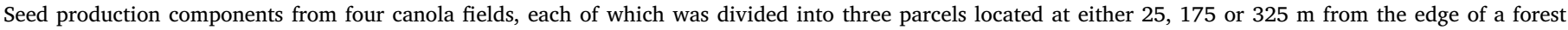
fragment in southern Brazil. All of the fields were accessible to insect visitors.

\begin{tabular}{|c|c|c|c|c|c|c|c|c|}
\hline Field & Distance (m) & $\begin{array}{l}\text { Number of flowers/ } \\
\text { plant (Mean } \pm \text { SD) }\end{array}$ & \% Fruiting & $\begin{array}{l}\text { Number of siliques/ } \\
\text { plant (Mean } \pm \text { SD) }\end{array}$ & $\begin{array}{l}\text { Mean number of } \\
\text { seeds/silique } \\
(n=10)\end{array}$ & $\begin{array}{l}\text { Mean number of } \\
\text { seeds/plant }\end{array}$ & $\begin{array}{l}\text { Weight of } 1000 \\
\text { seeds }(\mathrm{g})\end{array}$ & $\begin{array}{l}\text { Mean weight of } \\
\text { seeds /plant }\end{array}$ \\
\hline \multirow[t]{3}{*}{1} & $25(n=13)$ & $135 \pm 50$ & 79.8 & $108 \pm 41$ & $25 \pm 2^{a}$ & $2474 \pm 1211$ & $3.4 \pm 0.5^{\mathrm{a}}$ & $8.4 \pm 3.8^{\mathbf{a}}$ \\
\hline & $175(n=14)$ & $163 \pm 93$ & 82.7 & $135 \pm 79$ & $19 \pm 2^{b}$ & $2294 \pm 756$ & $2.8 \pm 0.3^{\mathrm{ab}}$ & $6.4 \pm 2.2^{\mathrm{a}}$ \\
\hline & $325(n=11)$ & $140 \pm 79$ & 70.5 & $99 \pm 62$ & $15 \pm 3^{c}$ & $1577 \pm 1114$ & $2.4 \pm 0.8^{\mathrm{b}}$ & $3.8 \pm 2.6^{\mathrm{b}}$ \\
\hline \multirow[t]{3}{*}{2} & $25(\mathrm{n}=13)$ & $144 \pm 71$ & $88.6^{\mathrm{a}}$ & $127 \pm 65$ & $22 \pm 4^{\mathrm{a}}$ & $2678 \pm 871^{\mathbf{a}}$ & $3.4 \pm 0.4$ & $9.2 \pm 3.3^{\mathbf{a}}$ \\
\hline & $175(n=13)$ & $211 \pm 144$ & $84.9^{\mathrm{a}}$ & $179 \pm 112$ & $20 \pm 3^{\mathbf{a}}$ & $1644 \pm 611^{a}$ & $3.2 \pm 0.4$ & $5.1 \pm 1.8^{\mathrm{b}}$ \\
\hline & $325(\mathrm{n}=13)$ & $210 \pm 92$ & $72.7^{\mathbf{b}}$ & $153 \pm 66$ & $18 \pm 3^{b}$ & $1530 \pm 617^{\mathbf{b}}$ & $3.0 \pm 0.7$ & $4.8 \pm 2.3^{c}$ \\
\hline \multirow[t]{3}{*}{3} & $25(n=18)$ & $251 \pm 112^{\mathbf{a}}$ & 75.2 & $189 \pm 80^{\mathrm{a}}$ & $25 \pm 3^{\mathrm{a}}$ & $3274 \pm 1085^{\mathbf{a}}$ & $3.6 \pm 0.5^{\mathrm{a}}$ & $11.6 \pm 3.3^{\mathrm{a}}$ \\
\hline & $175(\mathrm{n}=14)$ & $182 \pm 74^{b}$ & 76.3 & $139 \pm 54^{b}$ & $20 \pm 2^{b}$ & $1654 \pm 479^{b}$ & $3.7 \pm 0.2^{b}$ & $6.2 \pm 1.8^{\mathrm{b}}$ \\
\hline & $325(n=12)$ & $101 \pm 53^{c}$ & 78.6 & $79 \pm 39^{c}$ & $18 \pm 2^{c}$ & $1472 \pm 544^{c}$ & $3.2 \pm 0.4^{\mathrm{c}}$ & $4.7 \pm 1.7^{\mathrm{c}}$ \\
\hline \multirow[t]{3}{*}{4} & $25(n=14)$ & $261 \pm 143$ & 82.4 & $215 \pm 119$ & $23 \pm 2^{a}$ & $2650 \pm 726$ & $3.8 \pm 0.5^{\mathrm{a}}$ & $10.2 \pm 3.4$ \\
\hline & $175(n=14)$ & $259 \pm 179$ & 77.9 & $202 \pm 136$ & $20 \pm 2^{b}$ & $2499 \pm 647$ & $4.0 \pm 0.3^{\mathrm{a}}$ & $9.9 \pm 2.4$ \\
\hline & $325(\mathrm{n}=12)$ & $345 \pm 179$ & 80.0 & $276 \pm 115$ & $21 \pm 2^{\mathrm{ab}}$ & $2939 \pm 1080$ & $3.0 \pm 0.7^{b}$ & $8.6 \pm 3.1$ \\
\hline
\end{tabular}

Different letters (a, b and c) represent significant differences in the same column $(p<.05)$.

and; Field 3: $\left.\mathrm{F}_{1,36}=52.08, \mathrm{p}<.05\right)$, except Field $4\left(\mathrm{~F}_{1,36}=1.85\right.$, $\mathrm{p}>$.05). In Field 4 a decrease was observed, however the values did not differ statistically.

The productivity of canola seeds was most prominent $25 \mathrm{~m}$ from the edge of the forest fragments in all four fields. Additionally, there was a decrease in seed production as distance from a forest fragment increased (Table 2). The mean production of seeds at $25 \mathrm{~m}$ varied between 3368 and $4656 \mathrm{~kg} / \mathrm{ha}$, and the mean production of seeds at $175 \mathrm{~m}$ varied between 2044 and $3956 \mathrm{~kg} / \mathrm{ha}$. At $325 \mathrm{~m}$, the seed productivity varied between 1508 and $3432 \mathrm{~kg} / \mathrm{ha}$.

The seed yield per hectare was also reduced with increasing distance from a forest fragment, and a similar effect was observed for productivity (Table 2). The total yield of each the four fields, calculated according to their number of hectares, is presented in Table 2. The main reductions in income occurred in Field 2 (US\$ 41,520) and Field 3 (US\$ 80,400 ), with these fields possessing between 80 and 100 ha, respectively (Table 2). However, Field 4 had the same area as Field 2 (80 ha) but its income loss was lower (US\$15,040) (Table 2). We assumed that the most productive distance $(25 \mathrm{~m})$ and the least productive distance (325 m), therefore the sum of the losses across all fields was a total of US\$147,800, in production deficit found in the studied areas (Table 2). The loss of canola yield varied between 16 and 59\%. The greatest loss of production recorded along the distance gradient occurred in Field 3 (Table 2). Therefore, our findings show that canola yield is significantly and negatively affected by its distance from forest fragments (LMM, $t=-3.89, p<.0001$, Fig. 1, Table 1 in Supplementary file).

Table 2

Crop yield and income in four canola fields in three parcels open to insect visitation at 25,175 and $325 \mathrm{~m}$ from the edge of forest fragments in the municipality of Esmeralda in southern Brazil.

\begin{tabular}{llllll}
\hline Field & Distance (m) & $\begin{array}{l}\text { Yield } \\
\text { (kg/ } \\
\text { ha) }\end{array}$ & $\begin{array}{l}\text { Income } \\
\text { hectare }^{-1} \text { (US\$)) }\end{array}$ & $\begin{array}{l}\text { Total } \\
\text { income } \\
\text { of the } \\
\text { field (US } \\
\$ \text { ) }\end{array}$ & $\begin{array}{l}\text { Total } \\
\text { loss per } \\
\text { field (US } \\
\$ \text { \$)) }\end{array}$ \\
& & & & 19,620 & 10,840 \\
\hline 1 (20 ha) & 25 & 3368 & 981 & 14,920 & $(55 \%)$ \\
& 175 & 2560 & 746 & 8780 & \\
2 (80 ha) & 325 & 1508 & 439 & 86,080 & 41,520 \\
& 25 & 3692 & 1076 & 47,600 & $(48 \%)$ \\
3 (100 ha) & 25 & 2044 & 595 & 44,560 & \\
& 175 & 1912 & 557 & 135,600 & 80,400 \\
& 175 & 4656 & 1356 & 72,000 & $(59 \%)$ \\
4 (80 ha) & 25 & 2472 & 720 & 55,200 & \\
& 175 & 1896 & 552 & 94,960 & 15,040 \\
& 325 & 4076 & 1187 & 92,160 & $(16 \%)$ \\
& 3956 & 1152 & 79,920 & \\
\hline
\end{tabular}

\subsection{Scenarios of cost-benefit thresholds per field}

Based on field observations and georeferenced survey data, we identified (on a map) the shape and extent of the crops and their adjacent fragments of natural vegetation. Field 3benefited the most in every model (Table 2 and Fig. 2 in the Supplementary file). The results suggest that the relative cost of decreasing the planted area, which first reduced the total income, are not only compensated by the extra income generated over time but also by a significant increase in the total profitability of the field. Besides estimated income, yield increases appeared across the five models generated, with the best benefit threshold achieved in model 4 (Table 2 and Fig. 2 in the Supplementary file). In this model, a minimum extra income of $8.2 \%$ was generated at the expense of only approximately $4.7 \%$ of the planted area. Nevertheless caution is required when evaluating Field 3, as its particular wide and elongated shape could lead to an overestimation of the extra income in some models. Notably, the extra income values from models 1 to 4 are questionable due to the expansion of income values over the rings on the south side of Field 3, but the area of the NVP on the south side is not large enough to provide a suitable habitat for pollinators (see Figs. 3-6; e.g. models 1 to 4 in Fig. 2 of the Supplementary file). Taking this into account, model 5 is potentially the most reliable model, providing suitable habitat spots covering the entire length of the crop. The scenario consequently increases pollination and profitability while also contributing to the conservation of pollinators in the area.

In Field 3 the extra income produced from models 1 to 5 was highest at the center of the crop field and decreased towards the field's borders. This reflects the improved spatial configuration of the farmland. The models of Field 3 represent the widest distribution of extra income over the crop rings than any other fields that were observed. In addition, the converted areas of all models did not significantly reduce the total size of the remaining planted area, maintaining the conversion ratio between planted and NVP areas. Consequently, the costs of these scenarios could be kept at low across the models. The findings of these models suggest that large crops can benefit more from the conversion of their core areas into NVPs than small crops can.

The second most benefited crop field was Field 2 (Table 2 and Fig. 2 in the Supplementary file), showing positive extra income values in every model. The best benefit threshold was achieved in model 3, with a loss of approximately $4 \%$ of the planted area. However, income was increased by approximately $5.4 \%$ as a result. The area converted to a NVP in model $3(\sim 3.1$ ha) is big enough to be a suitable habitat for pollinators, and consequently this model is the most beneficial even when considering the costs involved. The crop field that benefitted the least in Delta Income (USD and in Delta Income in \%) was Field 1, which is also the smallest field ( 20 ha). It was observed that even a 


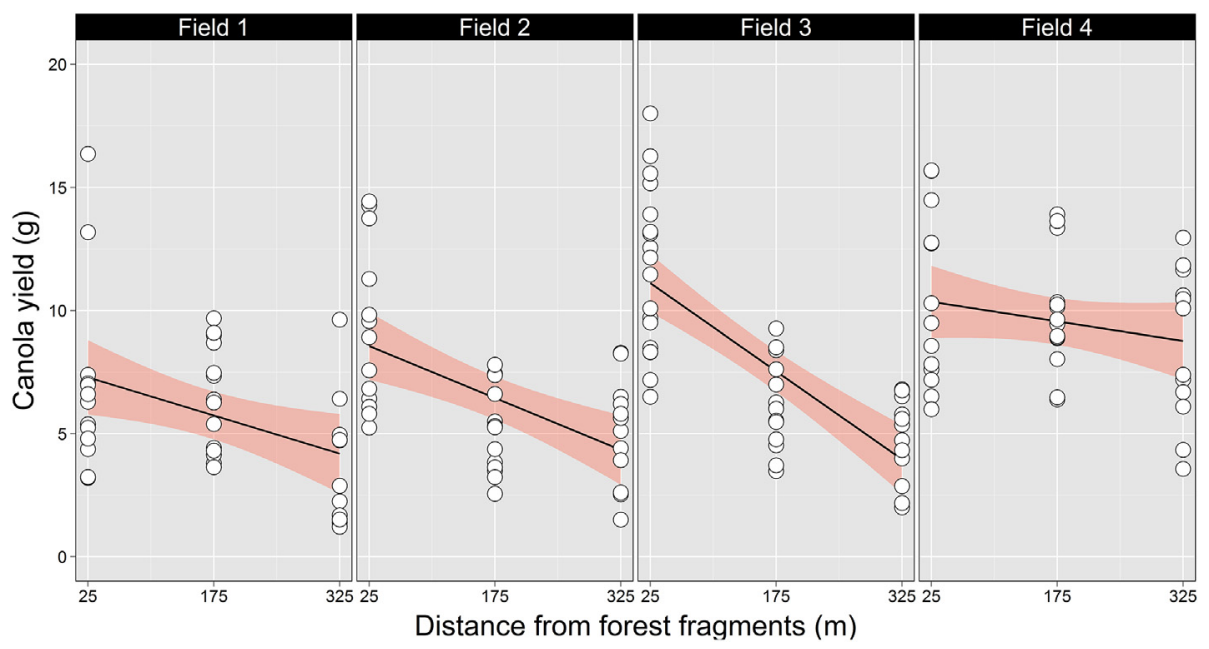

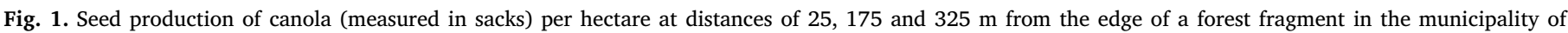
Esmeralda in southern Brazil. Note: Dots are observed values and solid lines show the linear best fit with $95 \%$ confidence intervals (shaded areas).

small loss of planted area was extremely costly for Field 1. The conversion of approximately 0.7 ha of planted area to a NVP, as performed in model 2 (Fig. 3), was identified to be the minimum suitable habitat size necessary to sustain pollinator populations ( 0.7 ha; about the area of football pitch) and increase the profitability of crops (with an income increase of about $1.4 \%$ ).

The worst general result was obtained for Field 4 (Table 2 and Fig. 2 in the Supplementary file). However, this result cannot be considered poor in terms of its profitability. This is because the models were unable to provide large extra incomes from the good income levels that were already present (model 0). Therefore, in this case the estimated conversions of parcels to NVP (models) was not able to significantly improve income levels.

Field 3 was the most profitable area (over 58,000 USD per total area; model 0 in Fig. 5) and Field 4 was the second most profitable area (over 54,000 USD per total area; model 0 in Fig. 6). Model 2 from Field 4 showed the maximum area conversion necessary to produce a profit. However, despite an increase of approximately 616 USD (Delta Income USD in Fig. 6) in this model, the relative income of this scenario is low, only about $1.2 \%$ (Delta Income given in \%). It should be noted that the area was not large enough ( 0.32 ha) to provide a suitable habitat for pollinators. Therefore, in general terms, the costs (loss of planted area)
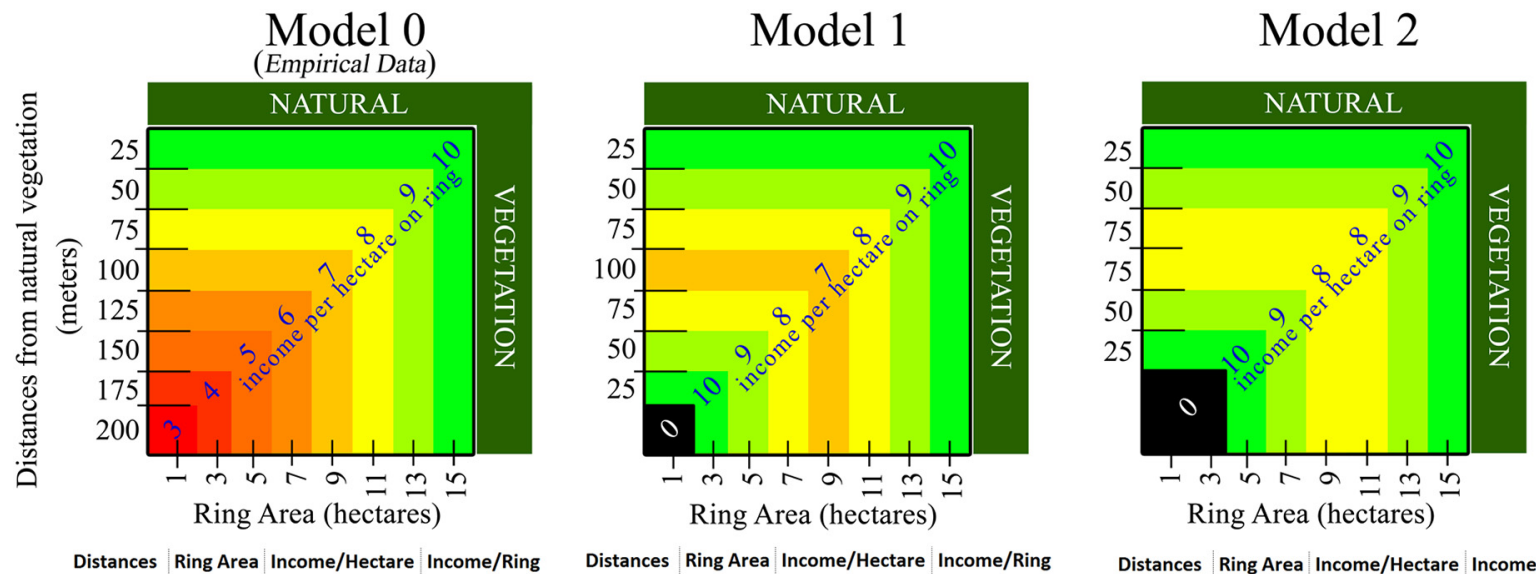

\begin{tabular}{|c|c|c|c|}
$\begin{array}{c}\text { Distances } \\
\text { (m) }\end{array}$ & $\begin{array}{c}\text { Ring Area } \\
\text { (ha) }\end{array}$ & $\begin{array}{c}\text { Income/Hectare } \\
\text { (USD/ha) }\end{array}$ & $\begin{array}{c}\text { Income/Ring } \\
\text { (USD) }\end{array}$ \\
\hline 200 & 1 & 3 & 3 \\
\hline 175 & 3 & 4 & 12 \\
\hline 150 & 5 & 5 & 25 \\
\hline 125 & 7 & 6 & 42 \\
\hline 100 & 9 & 7 & 63 \\
\hline 75 & 11 & 8 & 88 \\
\hline 50 & 13 & 9 & 117 \\
\hline 25 & 15 & 10 & 150 \\
\hline Total Area: & 64 & Total Income: & 500 \\
\hline Lost Area: & 0 & Extra Income: & 0 \\
\hline
\end{tabular}

\begin{tabular}{|c|c|c|c|}
\hline $\begin{array}{c}\text { Distances } \\
(\mathrm{m})\end{array}$ & $\begin{array}{c}\text { Ring Area } \\
\text { (ha) }\end{array}$ & $\begin{array}{c}\text { Income/Hectare } \\
\text { (USD/ha) }\end{array}$ & $\begin{array}{c}\text { Income/Ring } \\
\text { (USD) }\end{array}$ \\
\hline & 0 & 0 & 0 \\
\hline 25 & 3 & 10 & 30 \\
\hline 50 & 5 & 9 & 45 \\
\hline 75 & 7 & 8 & 56 \\
\hline 100 & 9 & 7 & 63 \\
\hline 75 & 11 & 8 & 88 \\
\hline 50 & 13 & 9 & 117 \\
\hline 25 & 15 & 10 & 150 \\
\hline Total Area: & 63 & \multirow{2}{*}{$\begin{array}{l}\text { Total Income: } \\
\text { Extra Income: }\end{array}$} & 549 \\
\hline Lost Area: & 1 & & 49 \\
\hline
\end{tabular}

\begin{tabular}{|c|c|c|c|}
$\begin{array}{c}\text { Distances } \\
(\mathbf{m})\end{array}$ & $\begin{array}{c}\text { Ring Area } \\
\text { (ha) }\end{array}$ & $\begin{array}{c}\text { Income/Hectare } \\
\text { (USD/ha) }\end{array}$ & $\begin{array}{c}\text { Income/Ring } \\
\text { (USD) }\end{array}$ \\
\hline & 0 & 0 & 0 \\
& 0 & 0 & 0 \\
& 5 & 10 & 50 \\
25 & 5 & 9 & 63 \\
50 & 7 & 8 & 72 \\
75 & 9 & 8 & 88 \\
75 & 11 & 9 & 117 \\
50 & 13 & 10 & 150 \\
\hline 25 & 15 & Total Income: & 540 \\
\hline Total Area: & 60 & Totra Income: & 40 \\
\cline { 1 - 1 } Lost Area: & 4 & Extra Inconn &
\end{tabular}

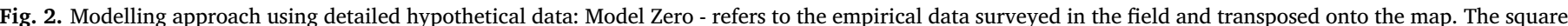

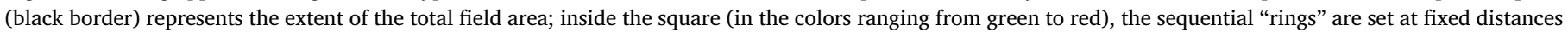

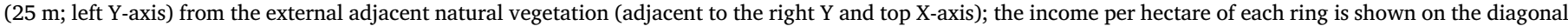

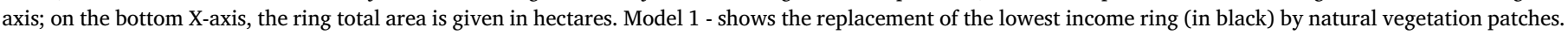

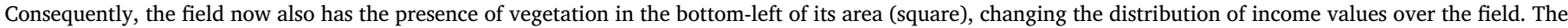

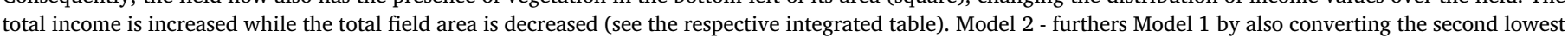

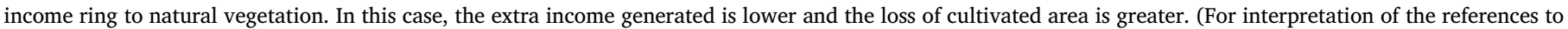
colour in this figure legend, the reader is referred to the web version of this article.) 

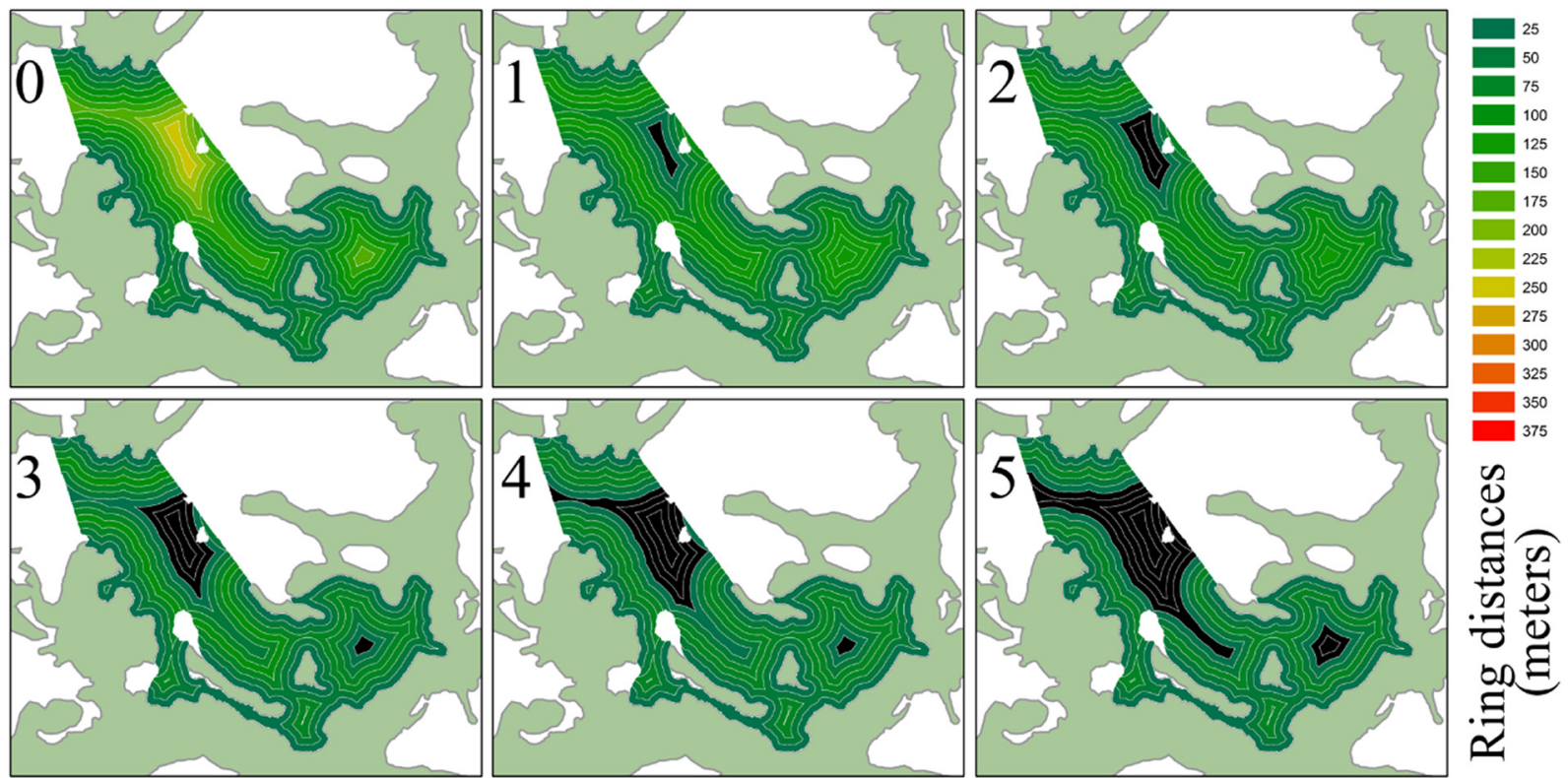

Fig. 3. Models based on Field 1. The numbers 1 to 5 represent the created models, while zero (0) refers to the empirical data collected. The black areas show the replacement of the lowest income area(s) (i.e. poorly pollinated arable lands) by natural vegetation patches, which work as potential habitats for pollinating organisms.
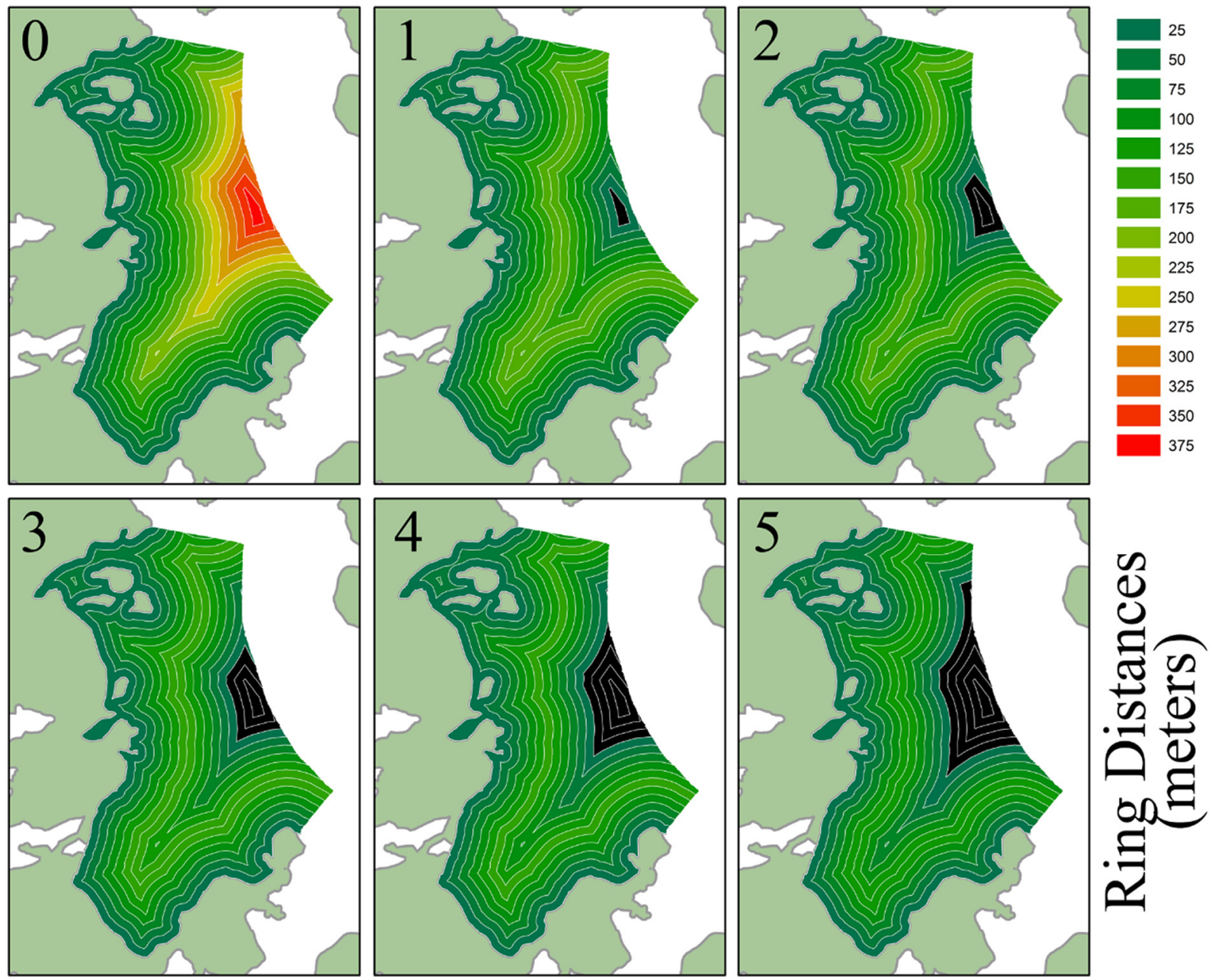

Fig. 4. Models based on Field 2. The numbers 1 to 5 represent the created models, while zero $(0)$ refers to the empirical data collected. The black areas show the replacement of the lowest income area(s) (i.e. poorly pollinated arable lands) by natural vegetation patches, which work as potential habitats for pollinating organisms. 

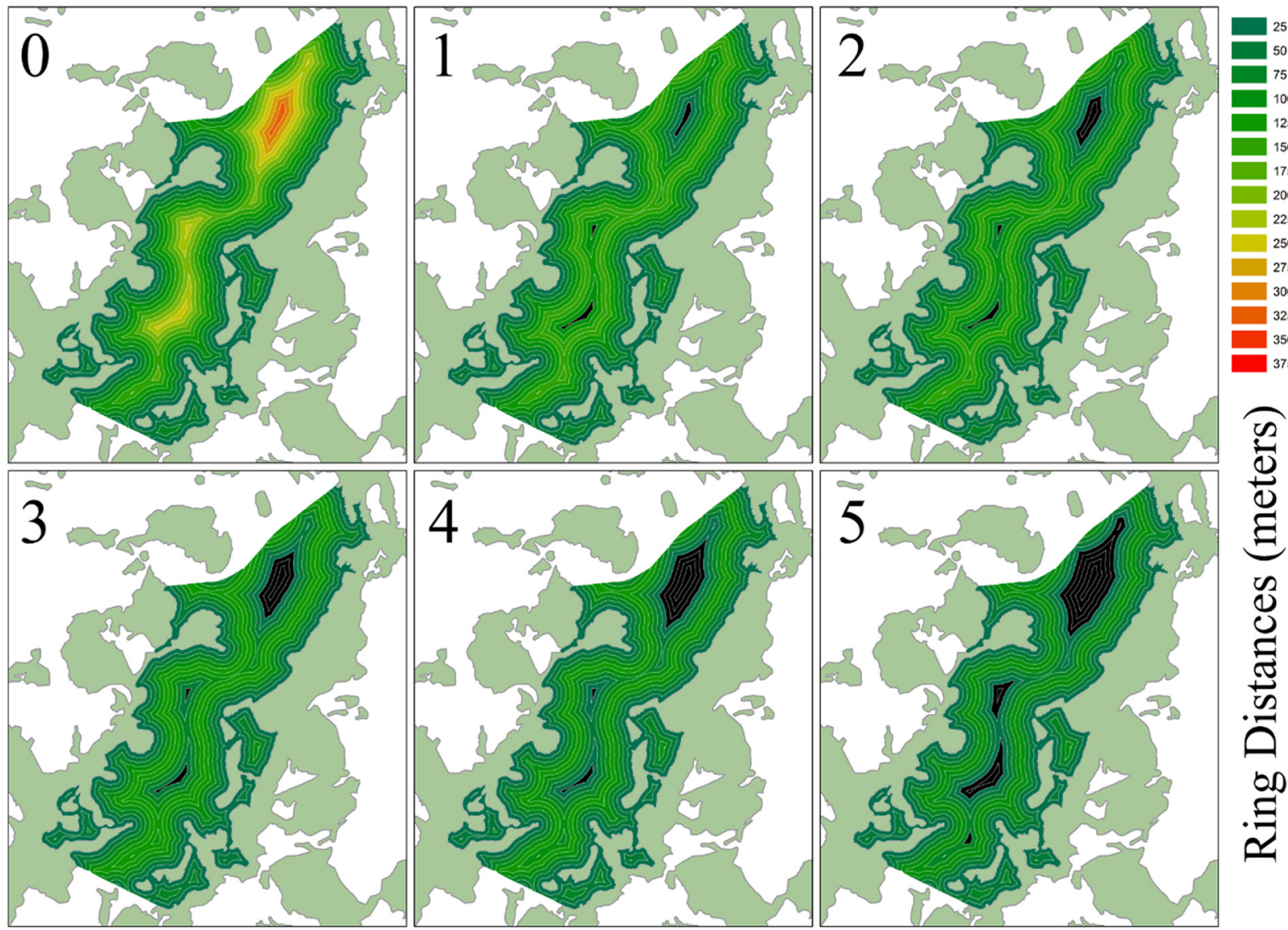

Fig. 5. Models based on Field 3. The numbers 1 to 5 represent the created models, while zero (0) refers to the empirical data collected. The black areas show the replacement of the lowest income area(s) (i.e. poorly pollinated arable lands) by natural vegetation patches, which work as potential habitats for pollinating organisms.

are not compensated by the benefits (extra income).

\section{Discussion}

\subsection{Yield and economic value of canola crops}

Studies of the components directly or indirectly related to crop production have recently been performed for crops such as canola, oat, soy and sunflower (Amorim et al., 2008; Coimbra et al., 2004; Hartwig et al., 2007; Tourino et al., 2002). Productivity of agricultural crops at economically viable levels is a result of numerous factors, including favorable environmental conditions during the plant's development cycle and the presence of pollinators in adjacent areas. Pollination by bees is rarely given an economic value in Brazil since pollination
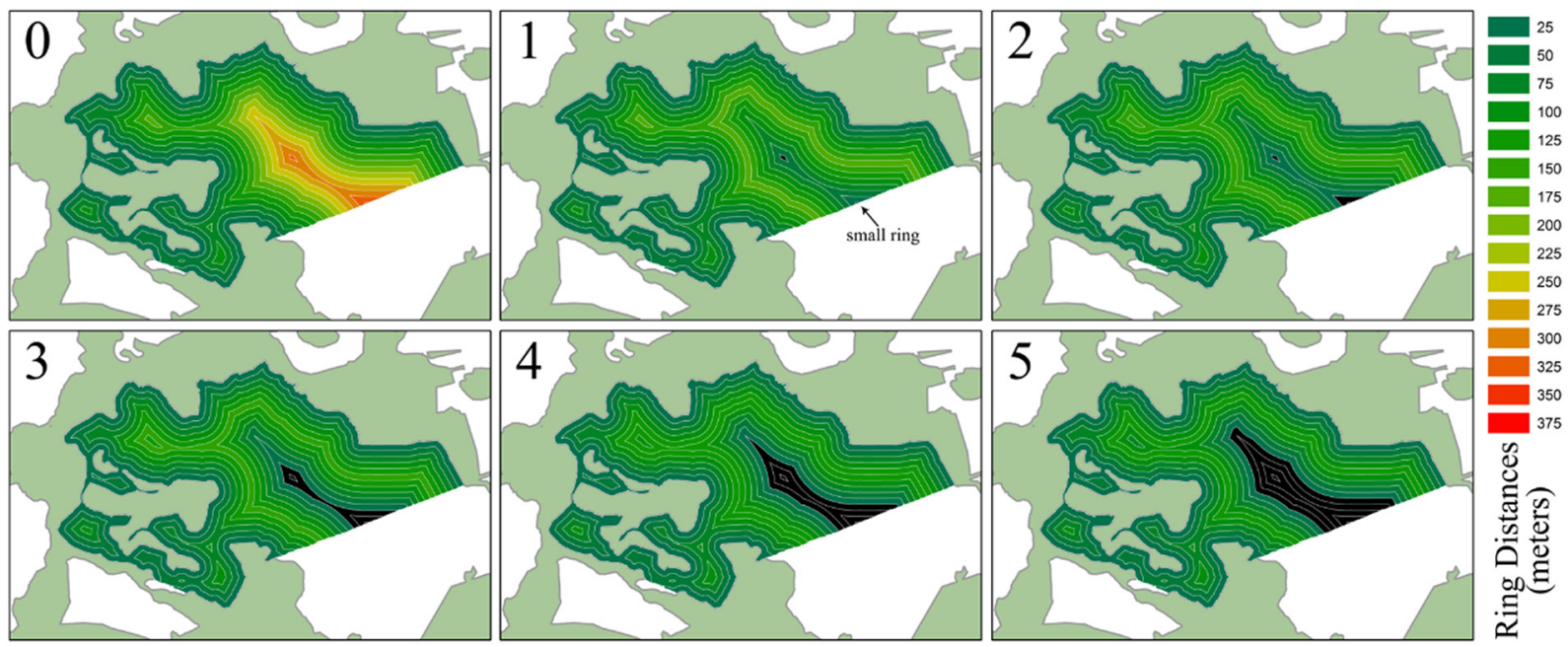

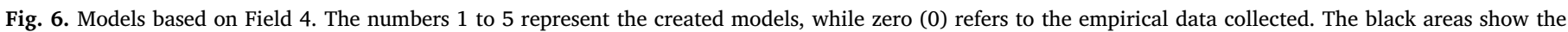

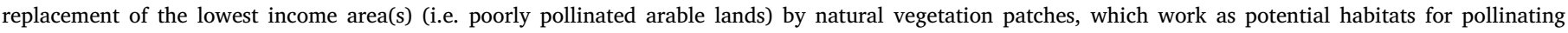
organisms. 
services are not considered as an important factor in the production of agricultural crops or in ecosystem conservation (Freitas and ImperatrizFonseca, 2005).

The yield of canola seeds is determined by factors related to agricultural practices, such as the number of plants per unit area. The final yield of canola seeds is obtained at the end of its entire maturation cycle. It is impacted by many biological factors, including the number of siliques per plant, number of seeds per silique and mean weight of seeds per plant (Coimbra et al., 1999; Franco and Carvalho, 1989). The mean number of flowers was similar in all fields except Field 3, where a decrease in the number of flowers was observed across the distance gradient (moving away from the forest edge). This fact may be due to unmeasured environmental conditions in this study, corroborated by the study of Krüger et al. (2011b). Therefore, the differences observed in the productivity of siliques and seeds at different distances from forest fragments cannot be attributed to the number of flowers.

The density of canola plants affects the number of siliques per plant and the number of seeds per silique (Diepenbrock, 2000). Here, plant density was observed to remain the same at different distances from forest fragments and the mean number of siliques per plant was also similar along the distance gradient, supporting the findings of Krüger et al. (2011a). However, Field 3 does not show the same results, potentially because abiotic conditions may have affected the mean number of siliques found along the distance gradient.

In the present study seed set was only a significant parameter in Field 2, which also showed a decrease in the rate of fruiting along the distance gradient (moving from the forest fragment into the crop field). This may be explained by the greater visitation of bees to areas located closer to the forest fragments (Chacoff and Aizen, 2006; de Marco and Coelho, 2004; Ricketts et al., 2004).

\subsection{Distance from a forest fragment and canola production}

Overall, it was demonstrated that distance from forest fragments significantly negatively affected canola production, as demonstrated in other studies (Bailey et al., 2014; Bartomeus et al., 2015; Morandin and Winston, 2006). Thus, our findings reinforce the relevance of forest fragments for pollination levels (Bailey et al., 2014; Bartomeus et al., 2015; Féon et al., 2013; Hipólito et al., 2018; Morandin and Winston, 2006). The weight of a thousand seeds did vary significantly along the distance gradient in the fields, especially between 25 and $325 \mathrm{~m}$. This is very interesting considering that the analyzed yield loss between these distances was on average $44.5 \%$. However, in Field 2 this pattern was not found.

In Canada the mean seed productivity of canola hybrids is $4500 \mathrm{~kg}$ / ha (Thomas, 2003), while the seed yield obtained in Brazil is $1236 \mathrm{~kg}$ / ha (Conab, 2019). In Brazil, the present study with the same cultivar of Brassica napus (Hyola 420) found that productivity exceeded these values at the distances closest to forest fragments (25 and $175 \mathrm{~m}$ ). This suggests that the maintenance of forest areas for pollinators is essential for increasing seed production.

It is known that 10 to $40 \%$ of the canola yield is dependent on pollinators (Gallai, 2008). Direct management has increased the production of numerous crops (Lonsdorf et al., 2009) by utilizing pollinator services provided by Apis mellifera Linnaeus 1758. Studies in Canada have shown that the introduction of three A. mellifera colonies per ha of canola fields increase productivity by $46 \%$ (Sabbahi et al., 2005). In Pakistan it was found that in controlled environments areas containing A. mellifera produced approximately three times more seed weight than areas which did not contain A. mellifera (Munawar et al., 2009). Additionally they found yield (in grams) to be five times higher when in the presence of $A$. mellifera.

Together, exotic and native bee species can increase the quality and fruit set of canola (Klein et al., 2003; Garibaldi et al., 2013). For some crops, native bees contribute to crop production as much or more than exotic species (Kevan et al., 1990). Thus, the reduction in abundance and diversity of both native and exotic bees seems to influence the productivity of agricultural crops in both natural areas and agroecosystems (Buchmann and Nabhan, 1996; Costanza et al., 1997). In addition, Rader et al. (2015) showed that non-bee insects are beneficial contributors to the production of oilseed. The value of pollination services incentivizes sustainable management of agricultural areas, bringing forth a reduction in forest losses and preventing the conversion of grasslands into farmland. Furthermore, knowledge of productivity components leads to yields that are more economically viable, facilitating competition in the grain and biofuel market.

The potential yield of a crop is determined by a theoretical evaluation of its maximum possible yield under optimal environmental conditions (Diepenbrock, 2000). As forest fragments contribute to these optimal environmental conditions they play an important role in determining grain yields and, consequently, profits. Therefore a loss in productivity along the distance gradient (moving away from forest fragments) can be inferred. Such productivity losses can lead to changes of up to $2760 \mathrm{~kg} / \mathrm{ha}$, which is equivalent to US\$ 804.08. Projections performed for the four studied fields suggest that if a forest fragment was not present, and that all of the fields only consisted of parcels equivalent to those at $325 \mathrm{~m}$, then the total income loss would be close to US\$ 147,800 , i.e., around US\$ 528 per hectare.

\subsection{Profitability of the NVP models}

It is well known that the natural environment around canola crops provides a large abundance and richness of bees, raising the crop's yields (Bartomeus et al., 2015; Morandin and Winston, 2005; Witter et al., 2015). Some studies suggest rethinking the design of agricultural landscapes to maximize their use of the ecosystem services provided by pollinator insects (Blaauw and Isaacs, 2014; Brosi et al., 2008; Carvalheiro et al., 2012; Isaacs et al., 2017; Landis, 2017; Picanço et al., 2017). Our comprehensive study adds to these papers, providing a solid foundation of research for scientists, stakeholders and farmers to design and coordinate common policies to progressively replace poorly pollinated parcels within crop fields by patches of natural vegetation. Less intensive agriculture contributes to an increase of wild pollinators within crops (Nicholson et al., 2017). The inclusion of natural vegetation areas within crop fields could offer bees more shelter and areas for foraging, thus optimizing the pollination coverage of the crop fields. The models presented here estimated whether the farmers were likely to have an increased or decreased yield $(\mathrm{kg} / \mathrm{ha})$, and consequently income (US\$), if they converted a few patches of arable land within their canola crop fields into natural vegetation.

The results evidence that model 1 may be the most profitable due to the common design of cultivated areas in the region, i.e., narrow belts of natural vegetation surrounding extensive agricultural areas. From this perspective, these traditional agriculture designs would appear to undergo a significant positive productivity boost if extra patches of natural vegetation were added inside the agricultural areas. Implementation of these changes could be performed progressively, firstly by replacing nonproductive or poorly pollinated areas by small patches of perennial native plants (Blaauw and Isaacs, 2014; Carvalheiro et al., 2012).

The factors contributing to losses instead of gains within in the models (for Field 3) are still unclear. Abiotic factors which were not measured probably influenced these results, even though several farming techniques and soil components were consistent across all evaluated fields. In Field 3, measures such as total loss per field reached $59 \%$, the highest loss of all the fields. Future projections are favorable, showing a planned increase in the number of seeds produced in Brazil. However, currently there is a significant deficit of 18 to $59 \%$ in productivity in the assessed fields.

How can extra NVPs inside crops boost canola production and the production of other cultivated plants? As previously mentioned, forest fragments provide large quantities of pollinating insects (mostly bees) 
which can raise the yield of canola if they are present during its blooming. At a glance, model 1 seems to provide unsuitable shelter and insufficient resources, such as food and nesting sites, for bee populations because of its small size. However, the majority of pollinators found in these areas were solitary bee species (Halinski et al., 2015), which tend to have small nests sincethey use underground holes as nesting sites. Additionally, some solitary bee species nest in the dried branches of trees and shrubs, places that could easily be found in small NVPs.

Social bees such as stingless bees were also found in the study areas (Halinski et al., 2015). Since stingless bees usually nest on trees and shrubs (Trigona sp.), or in the cavities of trunks, small NVPs may not provide appropriate shelter for such insects. However, taking into account that stingless bees (e.g. Tetragonisca fiebrigi and Plebeia emerina) are common and efficient pollinators of canola (Witter et al., 2015), then establishing hives of stingless bees should be considered as an additional form of canola management. Model 1 could include this natural scenario, whereas it would not be necessary within model 5, which consists of a larger NVP. Therefore, future studies are necessary to experimentally test whether the proposed models are, in fact, applicable and reliable. Such studies should take into account particular environmental conditions and biological features such as the presence and number of pollinating insects.

\section{Conclusion}

The canola flowers are open and receptive, containing pollen and nectar that attract a large number of pollinating insects, mainly bees. Similar studies have suggested that suitable forest fragments and grassland vegetation need to be preserved as reservoirs of pollinators in order to reduce the pollination deficit in canola crops. They suggest possible ways of connecting the pollinator fauna with the crop fields where they forage and nidificate. We believe that our model of maximum pollination coverage could be successful considering that bees looking for plants for foraging (flowers: nectar, pollen) and nesting (hollow in trees). However, the time when it will be available to farmers will depend if short-term or long-term strategies were adopted. Since herbaceous or woody plants grow and give first flowers at different periods, then, the expected maximum pollination coverage will be reached depending of proportion of vegetation types thought for each field. Here, we showed that including areas of natural vegetation close to or within crop fields provides more suitable habitat for the bees and consequently increases crop pollination. Additionally, this demonstrates that landscape management, for the benefit of bees, can also improve agricultural profits. In addition, we demonstrate a significant decrease in the mean number of seeds per silique and in seed production as the distance from forest fragment progressively increases and that parcels further than $325 \mathrm{~m}$ from forest fragments were poorly pollinated.

Therefore, the traditional practices commonly adopted by farmers worldwide resulting in few friendly acts to beneficial insects, i.e., by expanding their agricultural areas to compensate for the low and deficient productivity of canola, should be progressively replaced by the maintenance and/or recuperation of forest fragments. Furthermore, this could be a good strategy to promote and stimulate the introduction of suitable vegetation patches inside crop fields to perform pollination services. This method could increase seed production and the economic value of both the crops and pollination services. As the maximum pollination coverage of crops may be achieved when they are closer to forest fragments, replacing uncultivated and/or poorly pollinated parcels by natural vegetation patches can not only greatly benefit the pollinator species, but can also increase farmer's profits.

\section{Declaration of Competing Interest}

The authors don't have conflicts of interest.

\section{Acknowledgements}

We would like to thank Airton Scortegna for allowing field experiments to be conducted on his property. We thank Andressa Dorneles, Annelise Rosa and Mariana Fernandes for their field work harvesting the plants and Tatiana Kaehler for her Laboratory work processing the seeds. BB and RH would also like to thank the National Council for Scientific and Technological Development (CNPq) for the scholarships and funding ( $\mathrm{CNPq} 556635 / 2009-4)$ they provided, and are also grateful to the United Nations Environment Program/Global Environment Facility/Food and Agriculture Organization of the United Nations/Brazilian Biodiversity Fund (UNEP/GEF/FAO/FUNBIO) for the research funding. CFS is thankful to the Programa Nacional de PósDoutorado (PNPD) from the Coordenação de Aperfeiçoamento de Pessoal de Nível Superior (CAPES). A.L.A thanks the Research Center of Biodiversity and Computing (Biocomp.org.br) for providing the advanced computing infrastructure used to perform the geospatial modelling and analyses.

\section{Appendix A. Supplementary data}

Supplementary data to this article can be found online at https:// doi.org/10.1016/j.agsy.2019.102768.

\section{References}

Abrol, D.P., 2007. Honeybees and rapeseed: a pollinator-plant interaction. Adv. Bot. Res. 45, 337-367.

Aizen, M., Garibaldi, L., Cunningham, S., Klein, A., 2009. How much does agriculture depend on pollinators? Lessons from long-term trends in crop production. Ann. Bot. 103, 1579-1588. https://doi.org/10.1093/aob/mcp076.

Amorim, E.P., Ramos, N.P., Ungaro, M.R.G., Kiihl, T.A., 2008. Correlações e análise de trilha em girassol [correlations and path analysis of sunflower]. Bragantia 67 307-316.

Bailey, S., Requier, F., Nusillard, B., Roberts, S.P.M., Potts, S.G., Bouget, C., 2014. Distance from forest edge affects bee pollinators in oilseed rape fields. Ecol. Evol. 4, 370-380. https://doi.org/10.1002/ece3.924.

Bartomeus, I., Gagic, V., Bommarco, R., 2015. Pollinators, pests and soil properties interactively shape oilseed rape yield. Basic Appl. Ecol. 16, 737-745. https://doi.org/ 10.1016/j.baae.2015.07.004.

Bates, D., Maechler, M., Bolker, B., Walker, S., 2015. lme4: linear mixed-effects models using Eigenand S4. (R package version 1.1-9). Comput. Softw. 67 (1), 1-48. https:// doi.org/10.18637/jss.v067.i01. Retrieved from. https://CRAN.R-project.org/ package $=$ lme 4 .

Blaauw, B.R., Isaacs, R., 2014. Larger patches of diverse floral resources increase insect pollinator density, diversity, and their pollination of native wildflowers. Basic Appl. Ecol. 15, 701-711.

Blochtein, B., Nunes-Silva, P., Halinski, R., Lopes, L.A., Witter, S., 2014. Comparative study of the floral biology and of the response of productivity to insect visitation in two rapeseed cultivars (Brassica napus L.) in Rio Grande do Sul. Braz. J. Biol. 74, 787-794.

Bondin, O., Tengo, M., Norman, A., Lundberg, J., Elmqvist, T., 2006. The value of small size: loss of forest patches and ecological thresholds in southern Madagascar. Ecol. Appl. 16, 440-451.

Brosi, B.J., Armsworth, P.R., Daily, G.C., 2008. Optimal design of agricultural landscapes for pollination services. Conserv. Lett. 1, 27-36. https://doi.org/10.1111/j.1755263X.2008.00004.x.

Buchmann, S.L., Nabhan, G.P., 1996. The pollination crisis. Sciences 36, 22-27.

Carvalheiro, L.G., Seymour, C.L., Nicolson, S.W., Veldtman, R., 2012. Creating patches of native flowers facilitates crop pollination in large agricultural fields: mango as a case study. J. Appl. Ecol. 49, 1373-1383. https://doi.org/10.1111/j.1365-2664.2012. 02217.x.

Chacoff, N.P., Aizen, M.A., 2006. Edge effects on flower-visiting insects in grapefruit plantations bordering premontane subtropical forest. J. Appl. Ecol. 43, 18-27.

Coimbra, J.L.M., Guidolin, A.F., Júnior, A.M., Sangoi, L., Ender, M., Carvalho, F.I.F., 1999. Estabilidade fenotípica em genótipos de canola no planalto catarinense [PPhenotypic stability of canola genotypes in the Catarinense Plateau]. Científica Rural 4, 74-82.

Coimbra, J.L.M., Guidolin, A.F., de Almeida, M.L., Sangoi, L., Ender, M., Júnior, A.M., 2004. Análise de trilha dos componentes do rendimento de grãos em genótipos de canola [Path analysis of the components of seed yield in genotypes of canola]. Ciência Rural 34, 1421-1428.

Costanza, R., D’Arge, R., De Groot, R., Farber, S., Grasso, M., Hannon, B., Limburg, K., Naeem, S., O'Neill, R.V., Paruelo, J., Raskin, R.G., van der Belt, M., 1997. The value of the world's ecosystem services and natural capital. Nature 387, 253-260.

Daily, G.C., 1997. Nature's services: societal dependence on natural ecosystems, 3rd ed. Island Press.

de Marco, P., Coelho, F.M., 2004. Services performed by the ecosystem: forest remnants 
influence agricultural cultures pollination and production. Biodivers. Conserv. 13, 1245-1255.

Diepenbrock, W., 2000. Yield analysis of winter oilseed rape (Brassica napus L.): a review. Field Crop Res. 67, 35-49.

Durán, X.A., Ulloa, R.B., Carrillo, J.A., Contreras, J.L., Bastidas, M.T., 2010. Evaluation of yield component traits of honeybee-pollinated (Apis mellifera L.) rapeseed canola (Brassica napus L.). Chilean J. Agric. Res. 70, 309-314.

FAOSTAT, 2016. Food and agriculture organization of the united nations statistics division. http://faostat3.fao.org/download/Q/QD/E accessed 16 February 2016.

Féon, V., Burel, F., Chifflet, R., Henry, M., Ricroch, A., Vaissiére, B.E., Baudry, J., 2013. Solitary bee abundance and species richness in dynamic agricultural landscapes. Agric. Ecosyst. Environ. 166, 94-101. https://doi.org/10.1016/j.agee.2011.06.020.

Franco, F.A., Carvalho, F.I.F., 1989. Estimativa do progresso genético no rendimento de grãos de trigo e sua associação com diferentes caracteres sob o efeito de variação no ambiente [Estimate of genetic progress in the yield of wheat grains and its association with different characteristics under the effect of environmental variation]. Pesq. Agropec. Bras. 22, 311-321.

Freitas, B.M., Imperatriz-Fonseca, V.L., 2005. A importância econômica da polinização [The economic importance of pollination]. Mensagem Doce 80, 44-46.

Gallai, N., 2008. Array for the economic valuation of the contribution of insect pollination to agriculture and impact on the welfare [WWW Document]. In: FAOSTAT, . http:// www.internationalpollinatorsinitiative.org/uploads/POLLINATION VALUE ARRAY.xls.

Garibaldi, L.A., Steffan-dewenter, I., Winfree, R., Aizen, M.A., Bommarco, R., Cunningham, S.A., Kremen, C., Carvalheiro, L.G., Harder, L.D., Afik, O., Bartomeus, I., Benjamin, F., Boreux, V., Cariveau, D., Chacoff, N.P., Dudenhöffer, J.H., Freitas, B.M., Ghazoul, J., Greenleaf, S., Hipólito, J., Holzschuh, A., Howlett, B., Isaacs, R., Javorek, S.K., Kennedy, C.M., Krewenka, K.M., 2013. Wild pollinators enhance fruit set of crops regardless of honey bee abundance. Science 339, 1608-1611.

Giannini, T.C., Cordeiro, G.D., Freitas, B.M., Saraiva, A.M., Imperatriz-Fonseca, V.L., 2015. The dependence of crops for pollinators and the economic value of pollination in Brazil. J. Econ. Entomol. 108, 849-857. https://doi.org/10.1093/jee/tov093.

Halinski, R., Dorneles, A.L., Blochtein, B., 2015. Bee assemblage in habitats associated with Brassica napus L. Revista Brasileira de Entomologia 59 (3), 222-228. https://doi. org/10.1016/j.rbe.2015.07.001.

Hartwig, I., Carvalho, F.I.F.D., Oliveira, A.C.D., Vieira, E.A., Silva, J.A.G.D., Bertan, I., Ribeiro, G., Finatto, T., Reis, C.E.S., Busato, C.C., 2007. Estimativa de coeficientes de correlação e trilha em gerações segregantes de trigo hexaplóide [Estimate of the correlation and path coefficients in segregating generations of hexaploid wheat]. Bragantia 66, 203-218.

Hervé, M., 2015. RVAideMemoire: Diverse basic statistical and graphical functions. Retrieved from. https://cran.r-project.org/web/packages/RVAideMemoire/index. html.

Hipólito, J., Boscolo, D., Felipe, B., 2018. Landscape and crop management strategies to conserve pollination services and increase yields in tropical coffee farms. Agric. Ecosyst. Environ. 256, 218-225. https://doi.org/10.1016/j.agee.2017.09.038.

Ihaka, R., Gentleman, R., 1996. R: a language for data analysis and graphics. J. Comput. Graph. Stat. 5, 299-314.

Isaacs, R., Williams, N., Ellis, J., Pitts-Singer, T.L., Bommarco, R., Vaughan, M., 2017. Integrated crop pollination: combining strategies to ensure stable and sustainable yields of pollination-dependent crops. Basic Appl. Ecol. 22, 44-60. https://doi.org/ 10.1016/j.baae.2017.07.003.

Kevan, P.G., Clark, E.A., Thomas, V.G., 1990. Insect pollinators and sustainable agriculture. Am. J. Altern. Agric. 5, 13-22.

Klatt, B.K., Holzschuh, A., Westphal, C., Clough, Y., Smit, I., Pawelzik, E., Tscharntke, T., 2013. Bee pollination improves crop quality, shelf life and commercial value. Proc. R.Soc. 281, 1-8. https://doi.org/10.1098/rspb.2013.2440.

Klein, A.M., Steffan-Dewenter, I., Tscharntke, T., 2003. Fruit set of highland coffee increases with the diversity of pollinating bees. Proc. R. Soc. B 270, 955-961.

Klein, A.M., Vaissiere, B.E., Cane, J.H., Steffan-Dewenter, I., Cunningham, S.A., Kremen, C., 2007. Importance of pollinators in changing landscapes for world crops. Proc. R. Soc. B 274, 303-313.

Knight, M.E., Osborne, J.L., Sanderson, R.A., Hale, R.J., Martin, A.P., Goulson, D., 2009. Bumblebee nest density and the scale of available forage in arable landscapes. Insect Conserv. Diver. 2, 116-124.

Konietschke, F., Placzek, M., Schaarschmidt, F., Hothorn, L.A., 2015. nparcomp: an R software package for nonparametric multiple comparisons and simultaneous confidence intervals. J. Stat. Softw. 64, 1-17.

Krüger, C.A.M.B., da Silva, J.A.G., Medeiros, S.L.P., Dalmago, G.A., Sartori, C.O., Schiavo, J., 2011a. Arranjo de plantas na expressão dos componentes da produtividade de grãos de canola [arrangement of plants in the expression of componentes of canola grain productivity]. Pesq. Agropec. Bras. 46, 1448-1453.

Krüger, C.A.M.B., Silva, J.A.G., Medeiros, S.L.P., Dalmago, G.A., Gaviraghi, J., 2011b. Herdabilidade e correlação fenotípica de caracteres relacionados à produtividade de grãos e à morfologia da canola [heritability and phenotypic correlation of characteristics related to canola grain productivity and morphology]. Pesq. Agropec. Bras. 46, 1625-1632.

Landis, D.A., 2017. Designing agricultural landscapes for biodiversity-based ecosystem services. Basic Appl. Ecol. 18, 1-12. https://doi.org/10.1016/j.baae.2016.07.005.

Lautenbach, S., Seppelt, R., Liebscher, J., Dormann, C.F., 2012. Spatial and temporal trends of global pollination benefit. PLoS One 7 (4), e35954. https://doi.org/10. 1371/journal.pone.0035954.
Lonsdorf, E., Kremen, C., Ricketts, T., Winfree, R., Williams, N., Greenleaf, S., 2009 Modelling pollination services across agricultural landscapes. Ann. Bot. 103, 1589-1600.

Mcgregor, S.E., 1976. Insect Pollination of Cultivated Crop Plants. Washington D.C, Department of Agriculture.

Morandin, L.A., Winston, M.L., 2005. Wild bee abundance and seed production in conventional, organic, and genetically modified canola. Ecol. Appl. 15, 871-881.

Morandin, L.A., Winston, M.L., 2006. Pollinators provide economic incentive to preserve natural land in agroecosystems. Agric. Ecosyst. Environ. 116, 289-292. https://doi. org/10.1016/j.agee.2006.02.012.

Munawar, M.S., Raja, S., Siddique, M., Niaz, S., Amjad, M., 2009. The pollination by honeybee (Apis mellifera L.) increases yeild of canola (Brassica napus L.). Pakistan Entomologist 31 (2), 103-106.

Nicholson, C.C., Koh, I., Richardson, L.L., Beauchemin, A., Ricketts, T.H., 2017. Farm and landscape factors interact to affect the supply of pollination services. Agric. Ecosyst. Environ. 250, 113-122.

Novais, S.M.A., Nunes, C.A., Santos, N.B., D’Amico, A.R., Fernandes, G.W., Quesada, M., Braga, R.F., Neves, A.N.O., 2016. Effects of a possible pollinator crisis on food crop production in Brazil. PLoS One 11, 1-12. https://doi.org/10.1371/journal.pone. 0167292.

Picanço, A., Gil, A., Rigal, F., Borges, P.A.V., 2017. Pollination services mapping and economic valuation from insect communities: a case study in the Azores (Terceira Island). Nat. Conserv. 18, 1-25. https://doi.org/10.3897/natureconservation.18. 11523.

Potts, S.G., Biesmeijer, J.C., Kremen, C., Neumann, P., Schweiger, O., Kunin, W.E., 2010. Global pollinator declines: trends, impacts and drivers. Trends Ecol. Evol. 25, 345-353.

R Core Team, 2019. R: A language and environment for statistical computing. The $\mathrm{R}$ Foundationfor Statistical Computing, Vienna, Austria [Computer software]. Retrieved from. http://www.R-project.org/.

Rader, R., Batomeus, I., Garibaldi, L., Garratt, M.P.D., Howlett, B., Cunningham, S.A., Mayfield, M.M., Arthur, A.D., Andersson, G.K.S., Blanche, R., Bommarco, R., Brittain, C., Carvalheiro, L.G., Chacoff, N.P., Entling, M.H., Foully, B., Freitas, B.M., GemmillHerren, B., Ghazoul, J., Griffin, S., Gross, C.L., Herbertsson, L., Herzog, F., Hipólito, J., Jaggar, S., Jauker, F., Klein, A.M., Kleijn, D., Krishnan, S., Queiroz Lemos, C., Lindström, S.A.M., Mandelik, Y., Magalhães Monteiro, V., Nelson, W., Nilsson, L., Pattemore, D., de Oliveira, N., Pisanty, G., Potts, S.G., Reemer, M., Rundlöf, M., Sheffield, C.S., Scheper, J., Schüepp, C., Taki, H., Vergara, C.H., Viana, B.F., Woyciechowski, M., Winfree, R., 2015. Non-bee insects are important contributors to global crop pollination. Proc. Natl. Acad. Sci. https://doi.org/10.1073/pnas. 1517092112 .

Ricketts, T.H., Daily, G.C., Ehrlich, P.R., Michener, C.D., 2004. Economic value of tropical forest to coffee production. Proc. Nat. Acad. Sci. United States Am. 101, 12579-12582.

Ricketts, T., Regetz, J., Steffan-Dewenter, I., Cunningham, S.A., Kremen, C., Bogdanski, A., Gemmil-Herren, B., Greenleaf, S.S., Klein, A.M., Mayfield, M.M., Morandin, L.A., Ochieng, A., Viana, B.F., 2008. Landscape effects on crop pollination services: are there general patterns? Ecol. Lett. 11, 499-515.

Rosa, A.S., Blochtein, B., Ferreira, N.R., Witter, S., 2010. Apis mellifera (Hymenoptera: Apidae) as a potencial Brassica napus pollinator (cv. Hyola 432) (Brassicaceae), in southern Brazil. Braz. J. Biol. 70, 1075-1081.

Sabbahi, R., De Oliveira, D., Marceau, J., 2005. Influence of honey bee (Hymenoptera: Apidae) density on the production of canola (Crucifera: Brassicacae). J. Econ. Entomol. 98, 367-372.

Steffan-Dewenter, I., Tscharntke, T., 1999. Effects of habitat isolation on pollinator communities and seed set. Oecol. 121, 432-440.

Thomas, P., 2003. 2010. Canola Grower's Manual. Canola Council of Canada, Winnipeg. http://www.canolacouncil.org/canola_growers_manual.aspx (accessed 31 January 2013).

Tourino, M.C.C., Rezende, P.D., Salvador, N., 2002. Espaçamento, densidade e uniformidade de semeaduranaprodutividade e características agronômicas da soja [row spacing, plant density and intrarow plant spacing uniformity effect on soybean yield and agronomic characteristics]. Pesq. Agrop. Brasileira 37, 1071-1077.

United States Department of Agriculture, 2016. Available at. http://www.usda.gov.

Vaissière, B., Rodet, G., Cousin, M., Botella, L., Grossa, J., 1996. Pollination effectiveness of honey bee (Hymenoptera: Apidae) in a kiwifruit orchard. Horticult. Entomol. 89, 453-461.

Veloso, H.P., Oliveira-Filho, L.D., Vaz, A.M.S.F., Lima, M.P.M., Marquete, R., Brazao, J.E.M., 1992. Manual técnico da vegetação brasileira [Technical handbook of Brazilian plants]. IBGE, Rio de Janeiro.

Vianello, R.L., Alves, A.R., 1991. Meteorologia Básica e Aplicações [Basic Meteorology and Applications]. Imprensa Universitária, Viçosa.

Vicens, N., Bosch, J., 2000. Pollinating efficacy of Osmia cornuta and Apis mellifera (Hymenoptera: Megachilidae, Apidae) on red delicious apple. Environ. Entomol. 29, 235-240.

Witter, S., Nunes-Silva, P., Lisboa, B.B., Tirelli, F.P., Sattler, A., Hilgert-Moreira, S.B., Blochtein, B., 2015. Stingless bees as alternative pollinators of canola. J. Econ. Entomol. 108, 880-886. https://doi.org/10.1093/jee/tov096.

Conab, 2019. Companhia Nacional de Abastecimento., Accessed date: 15 November 2019.

ESRI, 2010. ArcGIS Desktop: Release 10. Environmental Systems Research Institute, Redlands, CA, Accessed date: 6 September 2018. 